Annals of Plant and Soil Research 23(3): 291-296 (2021)

https://doi.org/10.47815/apsr.2021.10072

\title{
Influence of fortified in situ rice residue compost and zinc nano fertilizer on growth and yield of rice (Oryza sativa L.) under rice cultivation methods
}

\author{
PRABHU V. ${ }^{1,2}$, SINGARAVEL R. $^{2}$ AND RAMAKICHENIN alias, BALAGANDHI B. ${ }^{3}$ \\ ${ }^{1}$ ICAR-Perunthalaivar Kamaraj Krishi Vigyan Kendra, Puducherry-605009 (India). \\ Received: April, 2021; Revised accepted: June, 2021
}

\begin{abstract}
This study was conducted during the kharif, 2020 at ICAR-Perunthalaivar Kamaraj Krishi Vigyan Kendra, Puducherry, India aimed to examine the effect of fortified in situ rice residue compost, zinc nano fertilizer on the growth and yield of rice under rice cultivation methods. The experiment was conducted in a split plot design; 3mainplots (TPR, DSR and AR) and eight subplots (fortified manures and nano zinc particles) with three replications. The results revealed that the TPRsignificantly improved tillers, LAI, productive tillers, panicle weight, grain and straw yield, zinc content and uptake and it was statistically on par with DSRand superior over AR. Nutrient management, fortified manure $+Z n O N P s(S P+F S)$ significantly registered higher growth and yield attributes, $\mathrm{Zn}$ content and uptake of rice over to $\mathrm{ZnO}$ seed priming alone, $\mathrm{ZnSO}_{4}$ and control. The PGPM, humic acid and seaweed extract fortified organic manures either FYM or rice residue compost, nano zinc as seed priming and foliar spray under TPR or DSR have the potential to maximize rice production without foregoing soil sustainability.
\end{abstract}

Keywords: Rice, fortified rice residue compost, nano zinc, cultivation methods, yield

\section{INTRODUCTION}

Rice (Oryza sativa L.) is the major staple crop and a mainstay for the rural population and their food security. India is the second-largest producer of rice. Transplanting rice (TPR) is the traditional system of rice crop establishment and pronounces to be most dominant in irrigated low land. TPR accounts for 21 per cent of operational cost and critically it takes energy of 30 persons per hectare per day. Due to scarcity of water and labour, the area under transplanted rice in world is declining. Depleted soil productivity and reduced groundwater level are the main challenges in present-day rice cultivation. It is known that 4000 litres of water are used to produce $1 \mathrm{~kg}$ of rice in many areas and even more water usage in states of Punjab, Haryana, Puducherry (Sharma et al., 2018). Water availability for agriculture and for rice cultivation, in particular, will be less in the future and hence, we need to explore a new range of water-saving technology for rice production. Direct-seeded rice (DSR) has emerged as a feasible alternative establishment method and reduces labour requirement of $34 \%$, shortens the crop duration by 7-10 days, cost of cultivation saving of $29 \%$ and can produce as much grain yield as that of the transplanted crop and similarly, aerobic rice cultivation (AR) is another less water and labour demanding technique in comparison to TPR. Dry seeding uses 15.3\% less water and increased nitrogen use efficiency than TPR. Straw is the only organic material available in significant quantities to most rice farmers, around $40 \%$ of N, $30-35 \%$ of $P, 80 \%$ of $\mathrm{K}$, and 40 to $50 \%$ of $S$ nutrient assimilated by rice crop remains in vegetative plant parts at crop maturity. On the other hand, rice straw composting is the best alternative to manage this resource, besidesits use for restoration of soil health. Straw contains various macro and micronutrients, which make a payment to the nutrient budgeting of farms if returned to the soil. The recent studies have indicated the combined application of biofertilizers \& bioagents along with rice straw @2.5-7.5 t ha ${ }^{-1}$ restored the soil health and promoted the induced rice systemic resistance for increasing the rice productivity to the tune of 7.1 to $7.9-10.1$ tha $^{-1}$ (Simarmataet al., 2016).

In India, Zn deficiency is reported to occur to the extent of $60 \%$ of the cultivable area that coincided with the reduction in crop yield and quality to the tune of $25-35 \%$. Nano fertilizers are useful over conventional fertilizers as they increase soil fertility, yield and quality parameters of the crop. They are non-toxic and less harmful to the environment and humans. Jangid et al. (2019) concluded that RDF + foliar

\footnotetext{
*Corresponding auther e-mail: prabhusskvk@gmail.com, ${ }^{2}$ Annamalai University, Annamalai Nagar, ${ }^{3}$ Department of Agriculture and Farmers Welfare, Puducherry, India.
} 
sprays of nano ZnO at 1000 ppm or 1500 ppm had recorded significantly higher grain and straw yield. Keerthana (2020) reported that application ZnO NPs through seed priming and foliar spray increased the growth and yield of rice besides improving the zinc content and uptake. The present study aimed with the objective to maximizing rice yield under various rice production systems through in situ decomposition of PGPM consortia and bioactive stimulants fortified rice residue and nano zinc application.

\section{MATERIAL AND METHODS}

The experiment was conducted at research farm of ICAR-Perunthalaivar Kamaraj Krishi Vigyan Kendra (PKKVK), Puducherry, Indiaduring the kharif, 2020. The site is located at $7.8 \mathrm{~km}$ away from the Bay of Bengal, geopositioned between $11^{\circ} 93^{\prime}$ North latitude and $79^{\circ} 77^{\prime}$ East longitude and 15 meters above MSL. The initial soil properties of the experiment site noted a pH 7.10, EC $0.19 \mathrm{dS} \mathrm{m}^{-1}$, available soil nutrient status indicated low organic carbon $\left(2.4 \mathrm{~g} \mathrm{~kg}^{-1}\right)$, low N (141 kg ha-1), high $\mathrm{P}_{2} \mathrm{O}_{5}(49 \mathrm{~kg}$ $\left.\mathrm{ha}^{-1}\right)$ medium $\mathrm{K}_{2} \mathrm{O}\left(168 \mathrm{~kg} \mathrm{ha}^{-1}\right)$ and DTPA-Zn $\left(1.02 \mathrm{mg} \mathrm{kg}^{-1}\right)$. The experiment was laid out in the split plot design with 3 main plots treatments, $M_{1}$ - Transplanted Rice (TPR), $M_{2}$ - Direct Sown under puddled condition (DSR), $\mathrm{M}_{3}$ - Aerobic Rice (AR) - Direct seed sown under unpuddled condition and 8 Sub Plots $\mathrm{T}_{1}-100 \%$ RDF (control), $\mathrm{T}_{2}-\mathrm{T}_{1}+\mathrm{ZnSO}_{4} @ 25 \mathrm{~kg} \mathrm{ha}^{-1}, \mathrm{~T}_{3}-75 \%$ RDF+ (PGPM consortia + BA compounds) fortified FYM @ 5t ha ${ }^{-1}+\mathrm{ZnSO}_{4} @ 25 \mathrm{~kg} \mathrm{ha}^{-1}, \mathrm{~T}_{4}$ - 75\% RDF+ In situ rice residue compost fortified (PGPM consortia + BA compounds) + $\mathrm{ZnSO}_{4} @$ $25 \mathrm{~kg} \mathrm{ha}^{-1}, \mathrm{~T}_{5}-75 \%$ RDF+ fortified FYM @ 5t ha ${ }^{1}+\mathrm{ZnO}$ NPs seed priming, $\mathrm{T}_{6}-75 \%$ RDF+ fortified Insitu rice residue compost $+\mathrm{ZnO}$ NPs seed priming, $T_{7}-T_{5}+Z n O N P s$ (foliar spray), and $_{8}-\mathrm{T}_{6}+\mathrm{ZnO}$ NPs (foliar spray). The PGPM cultures viz., Azospirillum, Phosphobacteria, potash solubilizing bacteria, zinc solubilizing bacteria, Pseudomonas fluorescence and Trichoderma sp. cultures were mixed in equal quantities to make consortia and fortified with FYM @ $2.8 \mathrm{~kg} \mathrm{t}^{-1}$. Bio Active compounds (BA) viz., humic acid and seaweed extract were also fortified with FYM @ $100 \mathrm{~mL} \mathrm{t}^{-1}$. Theinsitu incorporation of riceresidueswas carried out@ $7.5 \mathrm{t} \mathrm{ha}^{-1}$ at 20 days beforesowing / transplanting to ensure desirable decomposition and $\mathrm{N}$ deficiency due to immobilization. For in siturice residue fortification treatments PGPM consortia @ $14 \mathrm{~kg} \mathrm{ha}^{-1}$ and BA compounds @ $500 \mathrm{Ml} \mathrm{ha}^{-1}$ were sprinkled uniformly overriceresidues and incorporatedinto the soil. Irrigations at regular intervals were done to maintain adequate moisture for the decomposition of rice residues. The nutrient content of paddy residue and FYM are presented in Table 1.

Table 1: Nutrient content of rice residue and FYM

\begin{tabular}{c|c|c|c|c|c|c|c|c|}
\hline Organic manure & $\mathrm{pH}$ & $\mathrm{EC} \mathrm{dSm}^{-1}$ & $\mathrm{OC} \%$ & $\mathrm{~N}(\%)$ & $\mathrm{P}(\%)$ & $\mathrm{K}(\%)$ & $\mathrm{Zn}\left(\mathrm{mg} \mathrm{kg}^{-1}\right)$ & $\mathrm{Fe}\left(\mathrm{mg} \mathrm{kg}^{-1}\right)$ \\
\hline Rice residue & 7.28 & 3.42 & 34.7 & 0.47 & 0.22 & 1.08 & 30.4 & 115 \\
FYM & 7.04 & 2.28 & 16.5 & 0.51 & 0.24 & 0.49 & 68.8 & 162 \\
\hline
\end{tabular}

Zinc sulphate was applied @ $25 \mathrm{~kg} \mathrm{ha}^{-1}$ as soil application (SA), for nano zinc seed priming (SP) treatments, rice seeds were soaked in deionized water for 6 hours followed by soaking them in nano zinc solutions @ 1000 ppm for 6 hours, incubated for 12 hours and sown.Foliar spray of ZnONPs@500 ppm at panicle initiation and flowering stages were given to respective treatments. The rice variety ADT R 37 of 110 days duration was cultivated. The fertilizers were applied based on treatment levels following the recommended fertilizer schedule of 120:40:40 NPK kg ha-1 as urea, superphosphate and muriate of potash were applied as basal and the $50 \% \mathrm{~N}$ and $\mathrm{K}$ were applied at tillering and panicle initiation stages. Biometric observations viz., growth attributes, yield attributes and yield data were recorded at harvest stage. The grain and straw samples were analyzed for zinc content by adopting standard procedures and zinc uptake was computed. The datacollected from the study weresubjected to ANOVA in accordance with the experimental design (SPD) using AGRES statistical package and CD values were calculated at $5 \%$ level of significance (Gomez and Gomez, 1984). 


\section{RESULTS AND Discussion}

\section{Growth attributes}

DSR recorded the highest among the method of cultivation $(103.6 \mathrm{~cm})$, followed by TPR $(101.4 \mathrm{~cm})$ and AR $(98.4 \mathrm{~cm})$. Among the nutrient management, the highest plant height of $107.3 \mathrm{~cm}$ was observed with $\mathrm{S}_{8^{-}} 75 \%$ RDF+ fortified insitu rice residue $+\mathrm{ZnO} N P s(\mathrm{SP}+\mathrm{FS})$ irrespective of cultivation methods (Table 2). In nutrient management practices highest plant was recorded in insitu fortified rice residue compost + ZnO NPs (SP + FS), which might be due to fortification of FYM or rice residue with humic acid and seaweed extract (Kumar et al., 2014). Application of nano zinc fertilizer improved the zinc use efficiency and thereby improved the growth parameters of rice over $\mathrm{ZnSO}_{4}$ and control. The results corroborated with that of Singh et al.. (2019).
The number of tillers and LAI were recorded maximum with TPR -458 and 5.93, followed by DSR with 445 and 5.87 and the lowest with AR-403 and 5.35, respectively (Table 2). Among the nutrient management, $S_{8}$ fortified rice residue $+\mathrm{ZnO} \mathrm{NPs}(\mathrm{SP}+\mathrm{FS})$ recorded higher tillers of 507 and LAlof6.42 and it was comparable with same treatment with fortified FYM $\left(S_{7}\right)$ with 495 tillers and LAI of 6.33. The lowest tillers and LAl were recorded in the control. The maximum tillers and LAlwere obtained with TPR and DSR, which might be due to the low weed occurrence. These results were agreed to the findings of Sahu et al.(2018). Zinc improved the metabolic process of the plant, which lead to higher absorption of zinc and other essential nutrients for the growth and resulted in superior rice growth and tiller numbers. The results were obtained are in accordance with Aminah et al. (2019).

Table 2: Effect of rice cultivation methods, fortified organic manures and nano zinc on growth and yield attributes of rice

\begin{tabular}{|c|c|c|c|c|c|c|c|}
\hline Treatments & $\begin{array}{l}\text { Plant height } \\
\quad(\mathrm{cm})\end{array}$ & $\begin{array}{c}\text { No. of } \\
\text { tillers } / \mathrm{m}^{2}\end{array}$ & LAI & $\begin{array}{l}\text { Panicle } \\
\text { weight }(g)\end{array}$ & $\begin{array}{c}\text { Test } \\
\text { weight } \\
\text { (g) }\end{array}$ & $\begin{array}{l}\text { No. of filled } \\
\text { grains / } \\
\text { panicle }\end{array}$ & $\begin{array}{l}\text { No. of } \\
\text { productive } \\
\text { tillers } / \mathrm{m}^{2}\end{array}$ \\
\hline \multicolumn{8}{|l|}{ Rice cultivation methods (M) } \\
\hline$M_{1}-T P R$ & 101.4 & 458 & 5.93 & 3.88 & 23.3 & 136 & 384 \\
\hline$M_{2}-D S R$ & 103.6 & 445 & 5.87 & 3.74 & 23.3 & 132 & 369 \\
\hline$M_{3}-A R$ & 98.4 & 403 & 5.35 & 3.51 & 23.2 & 109 & 310 \\
\hline S. Ed & 0.49 & 4.74 & 0.07 & 0.09 & NS & 1.70 & 5.66 \\
\hline C.D $($ LSD $=0.05)$ & 1.37 & 13.17 & 0.20 & 0.25 & NS & 4.73 & 15.72 \\
\hline \multicolumn{8}{|l|}{ Nutrient management $(\mathrm{S})$} \\
\hline $\mathrm{S}_{1}-$ Control (100 \% RDF) & 93.5 & 359 & 4.91 & 3.41 & 22.8 & 103 & 290 \\
\hline \multirow{2}{*}{$\begin{array}{l}\mathrm{S}_{2}-\mathrm{S}_{1}+\mathrm{ZnSO}_{4} \mathrm{SA} @ 25 \mathrm{~kg} \mathrm{ha}^{-1} \\
\mathrm{~S}_{3}-75 \% \mathrm{RDF}+\text { Fortified FYM + } \\
\mathrm{ZnSO}_{4} \mathrm{SA} @ 25 \mathrm{~kg} \mathrm{ha}^{-1}\end{array}$} & 96.9 & 387 & 5.18 & 3.49 & 23.0 & 111 & 309 \\
\hline & 99.0 & 407 & 5.51 & 3.60 & 23.1 & 120 & 329 \\
\hline $\begin{array}{l}\mathrm{S}_{4^{-}} 75 \% \mathrm{RDF}+\text { Fortified insitu rice } \\
\text { residue + } \mathrm{ZnSO}_{4} \mathrm{SA} @ 25 \mathrm{~kg} \mathrm{ha}^{-1}\end{array}$ & 100.6 & 424 & 5.56 & 3.67 & 23.2 & 123 & 344 \\
\hline $\begin{array}{l}\mathrm{S}_{5}-75 \% \text { RDF+ Fortified FYM + } \\
\text { ZnO NPs (SP) }\end{array}$ & 101.7 & 444 & 5.86 & 3.74 & 23.3 & 129 & 366 \\
\hline $\begin{array}{l}\mathrm{S}_{6}-75 \% \mathrm{RDF}+\text { Fortified insitu rice } \\
\text { residue + ZnO NPs (SP) }\end{array}$ & 103.9 & 460 & 5.96 & 3.82 & 23.4 & 132 & 376 \\
\hline \multirow{2}{*}{$\begin{array}{l}\mathrm{S}_{7}-\mathrm{S}_{5}+\mathrm{ZnO} N \mathrm{NPs}(\mathrm{FS}) \\
\mathrm{S}_{8}-\mathrm{S}_{6}+\mathrm{ZnO} N P s(\mathrm{FS})\end{array}$} & 106.0 & 495 & 6.33 & 3.94 & 23.5 & 141 & 406 \\
\hline & 107.3 & 507 & 6.42 & 4.01 & 23.6 & 147 & 417 \\
\hline \multirow{2}{*}{$\begin{array}{l}\text { S. Ed } \\
\text { C.D }(\operatorname{LSD}=0.05)\end{array}$} & 1.48 & 10.37 & 0.09 & 0.08 & NS & 2.93 & 8.02 \\
\hline & 2.98 & 20.94 & 0.17 & 0.15 & NS & 5.91 & 16.19 \\
\hline \multicolumn{8}{|l|}{$M$ at $S$ interactions } \\
\hline S. Ed & NS & NS & 0.16 & NS & NS & 5.04 & 14.18 \\
\hline & NS & NS & 0.34 & NS & NS & 10.61 & 30.33 \\
\hline \multicolumn{8}{|l|}{$\mathrm{S}$ at $\mathrm{M}$ interactions } \\
\hline S. Ed & NS & NS & 0.15 & NS & NS & 5.07 & 13.89 \\
\hline C.D (LSD =0.05) & NS & NS & 0.30 & NS & NS & 10.24 & 28.04 \\
\hline
\end{tabular}




\section{Yield attributes}

TPR plots noticed a higher number of productive tillers (384) and it was comparable with DSR (369) and least with AR (310) (Table 2). Among the nutrient managements, the highest productive tillers were recorded with $75 \% \mathrm{RDF}+$ fortified rice residue compost $+\mathrm{ZnO}$ $\mathrm{NPs}(\mathrm{SP}+\mathrm{FS})$ and lowest with control (100\% RDF) with 417 and 290, respectively.TPR with $75 \% \mathrm{RDF}+$ fortified rice residue compost $+\mathrm{ZnO}$ NPs (SP+FS) recorded the highest productive tillers than other combinations (Ishfaq, 2020). Nano zinc application increased the $\mathrm{Zn}$ uptake by rice which played a significant role in metabolic, physiological and biochemical activities which aided in producing the higher number of productive tillers (Kheyri et al.., 2019).

The test weight ranged from 23.2 to 23.3 $\mathrm{g}$ invarious cultivation methods and 22.8 to 23.6 in nutrient management practices (Table 2). This could probably due to the genetic character of the variety. TPR recorded a higher panicle weight and number of filler grains with $3.88 \mathrm{~g}$ and 136 , followed by DSR $-3.74 \mathrm{~g}$ and 132 and lowest with AR $-3.51 \mathrm{~g}$ and 109 , respectively. The highest and the lowest panicle weight and number of filled grains were recorded with $S_{8}$ fortified rice residue $+\mathrm{ZnO} N P s(\mathrm{SP}+\mathrm{FS})-4.01$ $\mathrm{g}$ and 147 and control- $3.41 \mathrm{~g}$ and 103, respectively. The finding corroborates with the results of Jusoh et al. (2013).

Table 3: Effect of rice cultivation methods, fortified organic manures and nano zinc on yield, zinc content and uptake of rice

\begin{tabular}{|c|c|c|c|c|c|c|}
\hline \multirow[b]{2}{*}{ Treatments } & \multirow{2}{*}{$\begin{array}{l}\text { Grain } \\
\text { yield } \\
\mathrm{t} \mathrm{ha}^{-1}\end{array}$} & \multirow{2}{*}{$\begin{array}{l}\text { Straw } \\
\text { yield } \\
\mathrm{t} \mathrm{ha}^{-1}\end{array}$} & \multicolumn{2}{|c|}{ Grain } & \multicolumn{2}{|c|}{ Straw } \\
\hline & & & $\begin{array}{c}\text { Zn Content } \\
\left(\mathrm{mg} \mathrm{kg}^{-1}\right)\end{array}$ & $\begin{array}{c}\text { Zn Uptake } \\
\left(\mathrm{g} \mathrm{ha}^{-1}\right)\end{array}$ & $\begin{array}{l}\text { Zn Content } \\
\left(\mathrm{mg} \mathrm{kg}^{-1}\right)\end{array}$ & $\begin{array}{c}\text { Zn Uptake } \\
\left(\mathrm{g} \mathrm{ha}^{-1}\right)\end{array}$ \\
\hline \multicolumn{7}{|l|}{ Rice cultivation methods (M) } \\
\hline$M_{1}-T P R$ & 5.62 & 7.16 & 27.42 & 157.1 & 36.31 & 264.3 \\
\hline$M_{2}-D S R$ & 5.44 & 6.96 & 26.86 & 149.0 & 35.12 & 249.0 \\
\hline$M_{3}-A R$ & 4.64 & 5.76 & 23.67 & 111.0 & 32.14 & 186.8 \\
\hline S. Ed & 0.10 & 0.08 & 0.38 & 3.01 & 0.63 & 4.93 \\
\hline \multicolumn{7}{|l|}{ Nutrient management (S) } \\
\hline $\mathrm{S}_{1}$ - Control (100\% RDF) & 4.29 & 5.49 & 19.12 & 82.2 & 26.93 & 148.5 \\
\hline $\mathrm{S}_{2}-\mathrm{S}_{1}+\mathrm{ZnSO}_{4} \mathrm{SA} @ 25 \mathrm{~kg} \mathrm{ha}^{-1}$ & 4.67 & 5.75 & 21.44 & 100.4 & 29.23 & 168.5 \\
\hline $\begin{array}{l}\mathrm{S}_{3}-75 \% \text { RDF+ Fortified FYM + } \\
\mathrm{ZnSO}_{4} \mathrm{SA} @ 25 \mathrm{~kg} \mathrm{ha}^{-1}\end{array}$ & 4.93 & 6.21 & 24.52 & 121.3 & 32.42 & 202.0 \\
\hline $\begin{array}{l}\mathrm{S}_{4}-75 \% \mathrm{RDF}+\text { Fortified insitu rice } \\
\text { residue }+\mathrm{ZnSO}_{4} \mathrm{SA} @ 25 \mathrm{~kg} \mathrm{ha}^{-1}\end{array}$ & 5.11 & 6.46 & 25.32 & 129.9 & 34.22 & 221.6 \\
\hline $\begin{array}{l}\mathrm{S}_{5}-75 \% \mathrm{RDF}+\text { Fortified FYM }+\mathrm{ZnO} \\
\mathrm{NPS}(\mathrm{SP})\end{array}$ & 5.31 & 6.71 & 27.12 & 144.7 & 35.68 & 240.0 \\
\hline $\begin{array}{l}\mathrm{S}_{6}-75 \% \mathrm{RDF}+\text { Fortified insitu rice } \\
\text { residue + } \mathrm{ZnO} \text { NPs (SP) }\end{array}$ & 5.51 & 6.97 & 27.86 & 154.0 & 36.51 & 255.0 \\
\hline \multirow{2}{*}{$\begin{array}{l}\mathrm{S}_{7}-\mathrm{S}_{5}+\mathrm{ZnO} N P s(\mathrm{FS}) \\
\mathrm{S}_{8}-\mathrm{S}_{6}+\mathrm{ZnO} N P s(\mathrm{FS})\end{array}$} & 5.96 & 7.61 & 30.90 & 186.0 & 40.18 & 308.7 \\
\hline & 6.08 & 7.79 & 31.59 & 193.8 & 41.00 & 322.9 \\
\hline S. Ed & 0.10 & 0.13 & 0.63 & 4.25 & 0.93 & 7.48 \\
\hline C.D (LSD =0.05) & 0.20 & 0.26 & 1.28 & 8.58 & 1.88 & 15.09 \\
\hline $\mathrm{M}$ at $\mathrm{S}$ interactions & & & & & & \\
\hline S. Ed & 0.19 & 0.23 & 1.09 & 7.52 & 1.63 & 13.08 \\
\hline \multirow{2}{*}{$\begin{array}{l}\text { C.D }(\text { LSD }=0.05) \\
S \text { at } M \text { interactions }\end{array}$} & 0.42 & 0.48 & 2.31 & 16.09 & 3.49 & 27.81 \\
\hline & & & & & & \\
\hline \multirow{2}{*}{$\begin{array}{l}\text { S. Ed } \\
\text { C.D }(\text { LSD }=0.05)\end{array}$} & 0.17 & 0.23 & 1.10 & 7.36 & 1.61 & 12.95 \\
\hline & 0.35 & 0.46 & 2.22 & 14.86 & 3.26 & 26.14 \\
\hline
\end{tabular}

\section{Grain and straw yield}

TPR recorded significantly higher grain and straw yield of 5.62and $7.16 \mathrm{t} \mathrm{ha}^{-1}$, respectively and it was superior over AR (grain yield $-4.64 \mathrm{t} \mathrm{ha}^{-1}$ and straw yield $\left.-5.76 \mathrm{t} \mathrm{ha}^{-1}\right)$ and comparable with DSR (grain yield $-5.44 \mathrm{t} \mathrm{ha}^{-1}$ and straw yield $\left.-6.96 \mathrm{t} \mathrm{ha}^{-1}\right)$. The grain yield 
increase in TPR was 3.45 and $21.24 \%$ over DSR and $A R$, respectively. Among the nutrient managements, the highest grain and straw yield of 6.08 and $7.79 \mathrm{t} \mathrm{ha}^{-1}$ was recorded with $\mathrm{S}_{8}-75 \%$ $\mathrm{RDF}+$ insitu rice residue fortified with PGPM, humic acid and seaweed extract $+\mathrm{ZnO}$ NPs $(\mathrm{SP}+\mathrm{FS})$ irrespective of cultivation methods. The $\mathrm{S}_{1}$ - control recorded the lowest grain and straw yield of 4.29 and $5.49 \mathrm{tha}^{-1}$. The significantly higher grain and straw yield were noticed with fortified rice residue/FYM + ZnO NPs $(\mathrm{SP}+\mathrm{FS})$ under TPR and DSR (Liu et al., 2015). Fortification of rice residue with PGPM and Bio Active compounds resulted in increased nutrient availability, the efficiency of fertilizers led to higher plant growth and yield attributes and thus resulted in higher yield of rice. These findings acknowledged with results obtained by Simarmata et al. (2016).Application of ZnO NPs improved the yield in rice over the control and $\mathrm{ZnSO}_{4}$ application which maybe because of the delivery of $\mathrm{Zn}$ nutrient through $\mathrm{ZnO}$ NPs in the right dose and right size aided in enhancing the growth and yield attributes of rice crop. Similar findings were reported by Kheyri et al.(2019).

\section{Zinc content and uptake}

The TPR recorded significantly higher grain and straw $\mathrm{Zn}$ content of $27.42,36.31 \mathrm{mg}$ $\mathrm{kg}^{-1}$ and $\mathrm{Zn}$ uptake of 157.1 and $264.3 \mathrm{~g} \mathrm{ha}^{-1}$, respectively (Table 3 ). The lowest $\mathrm{Zn}$ content

\section{REFERENCES}

Aminah, S., Hanum, H. and Sarifuddin (2019) The effects of potassium, nitrogen and straw compost giving to increase organic material levels and $\mathrm{k}$-exchangeable rice fields and rice growth. IOP conf. series: Earth and Environmental Sciences 260, 012130

Bala, R., Kalia, A. and Dhaliwal, S.S. (2019) Evaluation of efficacy of ZnO nanoparticles as Remedial Zinc nanofertilizer for Rice. Journal of Soil Science and Plant Nutrition.19: 379-389.

Ishfaq, M., Akbar, N., Anjum, S.A., Anwar-Ulhaq, M. (2020) Growth, yield and water productivity of dry direct seeded rice and transplanted aromatic rice under different irrigation management regimes. Journal and uptake were recorded in AR $23.67 \mathrm{mg} \mathrm{kg}^{-1}$ and $111.0 \mathrm{~g} \mathrm{ha}^{-1}$ (grain) and $32.14 \mathrm{mg} \mathrm{kg}^{-1}$ and $186.8 \mathrm{~g} \mathrm{ha}^{-1}$ (straw). Among the nutrient management, fortified rice residue plus zinc supplement through nano particles as SP and FS observed higher grain and straw $\mathrm{Zn}$ content and uptake 31.59 and $41.00 \mathrm{mg} \mathrm{kg}^{-1}$ and 193.8 and $322.9 \mathrm{~g} \mathrm{ha}^{-1}$, respectively Among the interactions, TPR and DSR with fortified rice residue or FYM + ZnO NPs recorded significantly higher $\mathrm{Zn}$ content and uptake. Since the diameter of ZnO NPs diameter less than the stomatal pore size can penetrate and move inside plant tissues may be attributed to the increased zinc transport and deposition. Thus, these findings emphasize the role of $\mathrm{ZnO} N P s$ in remediation of $Z n$ deficiency and improvement in the yield and $\mathrm{Zn}$ content in rice as reported by Bala et al. (2019).

From this study, it can be concluded that TPR showed its superiority among the establishment methods, in situ incorporation of fortified rice residues compost and nano zinc application as seed priming and foliar spray significantly increased the growth and yield of rice and saves inorganic fertilizers considerably. Thus, PGPM, humic acid and seaweed extract fortified organic manures either FYM or rice residue compost, nano zinc as seed priming and foliar spray under TPR or DSR have the potential to maximize rice production without foregoing soil sustainability.

of Integrative Agriculture 19(11): 26562673.

Jangid, B., Srinivas, A., Kumar, R.M., Ramprakash, T., Prasad, T.N.V.K.V., Kumar, K.A., Reddy S. N. and Dilal. V.K. (2019) Influence of zinc oxide nano particle foliar application on zinc uptake of rice under different establishment methods, International Journal of chemical studies 7(1): 257-261.

Jusoh, M.L.C., Manaf, L.A. and Latiff, P.A. (2013) Composting of rice straw with Effective Microorganisms (EM) and its influence on compost quality. Iranian Journal of Environmental Health Science \& Engineering 10: 17.

Keerthana, K.K. (2020) Effect of zinc nano fertilizer on the growth, yield and 
biofortification of rice in coastal saline soil M.Sc. (Agri) Thesis, Annamalai University, Tamil Nadu.

Kheyri,N., Hossein Ajam Norouzi, Hamid Reza Mobasser, and Benjamin Torabi. (2019) Effects of Silicon and Zinc nano particles on growth yield and biochemical characters of rice. Agronomy Journal 111:1-7.

Kumar, D., Singh, A.P., Raha, P. and Singh, C.M. (2014) Effects of potassium humate and chemical fertilizers on growth, yield and quality of rice (Oryza sativa L.). Bangladesh Journal of Botany 43 (2): 183-189.

Liu, H., Hussain, S., Zheng, M. Peng, S., Huang, J., Cui, K. and Nie,L. (2015) Dry direct-seeded rice as an alternative to transplanted-flooded rice in Central China. Agronomy for Sustainable Development 35: 285-294.

Sahu, K.K., Kumar, K., Diwan, U.K. and Pasupalk, S. (2018) Effect of Different Plant Establishment Techniques on Yield and Yield Components of Rice (Oryza sativa L.) varieties in East \& South East Coastal Plain of Odisha, India. International Journal of Current Microbiology and Applied Sciences. 7(7): 4198-4203.

Sharma, B.R., Gulati, A., Mohan, G., Manchanda, S., Ray, I. and Amarasinghe, U. (2018) Water productivity mapping of major Indian crops. NABARD and CRIER, Pp1-182.

Simarmata, T., Hersanti, Turmuktini,T., Fitriatin, B.N., Setiawati, M.R. and Purwanto. (2016) Application of bioameliorant and biofertilizers to Increase the soil health and rice productivity. Hayati Journal of Biosciences 23:181-184.

Singh, K., Madhusudanan, M. and Ramawat, N. (2019) Synthesis and characterization of zinc oxide nano particles (ZnO NPs) and their effect on growth, $\mathrm{Zn}$ content and yield of rice (Oryza sativa L.). Journal of Multidisciplinary Engineering Sciences and Technology 6(3): 9750-9754. 